\title{
Patient Satisfaction on Surgical Service Decision Time in Emergency Department of A Tertiary Hospital in Indonesia
}

\author{
Shabrina Adzania, ${ }^{1}$ Nucki Nursjamsi Hidajat, ${ }^{2}$ Elsa Pudji Setiawati ${ }^{2}$ \\ ${ }^{1}$ Faculty of Medicine Universitas Padjadjaran, Indonesia, ${ }^{2}$ Department of Orthopedic and \\ Traumatology Faculty of Medicine Universitas Padjadjaran/Dr. Hasan Sadikin General Hospital \\ Bandung, Indonesia, ${ }^{3}$ Department of Public Health Faculty of Medicine Universitas Padjadjaran, \\ Indonesia
}

\section{Abstract}

Background: Patient satisfaction survey is essential for evaluating and developing plans to improve health services' quality. One of the emergency department service quality indicators is decision time. Overcrowding of the emergency room as a result of long decision time may cause dissatisfaction among patients. This study aimed to evaluate the satisfaction level of patients receiving surgical services and the correlation between the satisfaction level and surgical service decision time.

Methods: A cross-sectional descriptive analytical study was conducted from September to November 2019 at the Emergency Department of Dr. Hasan Sadikin General Hospital. The consecutive sampling method was applied and a total of 110 patients met the inclusion and exclusion criteria. Patient satisfaction was assessed using a validated questionnaire and data on decision time was obtained from the patient's medical record. Spearman correlation test was used to analyze the data.

Result: This study discovered that most of the respondents were satisfied with the service (92.7\%) and that decision was mostly made in less than 2 hours $(79.1 \%)$. A weak negative correlation $(\rho=-0.144)$, was identified between decision time and patient satisfaction, albeit insignificant $(\mathrm{p}=0.067)$, with a confidence interval of $95 \%(\alpha=5 \%)$.

Conclusions: This study suggested that there is no correlation between patient satisfaction and decision time. Thus, decision time is not the main factor that determines patient satisfaction.

Keywords: Decision time, emergency department, patient satisfaction, service quality, surgery

\section{Introduction}

Patient satisfaction is often used as an imperative source of information to evaluate and develop a plan to improve health services' quality. ${ }^{1}$ Patient satisfaction is associated with patient compliance undergoing therapy and patients' tendency to choose their healthcare provider. ${ }^{2,3}$

The emergency department (ED) has to maintain the quality of its services to deliver effective and efficient patient care. Among all of the emergency cases, surgical patients with emergency conditions have a high risk of getting complications after procedures, medical errors, and death. ${ }^{4}$ At least $60 \%$ of surgical cases in lower-middle income countries are emergency. ${ }^{5}$ Decision time is one of the service quality indicators that is being evaluated in the surgical services of the ED. The study from Iran shows that emergency patients' satisfaction score has a negative correlation with the dimension of time. ${ }^{6}$

The objectives of this study were to evaluate the patient satisfaction receiving surgical services in the Emergency Department of Dr. Hasan Sadikin General Hospital, the top referral hospital in West Java Indonesia, and to assess its correlation with surgical services decision time.

\section{Methods}

A descriptive-analytic study with a crosssectional design was conducted from September to November 2019. The ethical

Correspondence: Shabrina Adzania, Faculty of Medicine Universitas Padjadjaran, Jalan Raya Bandung-Sumedang Km. 21, Jatinangor, Sumedang, Indonesia, Email: shabrina.adzania@gmail.com 
approval number from the Research Ethics Committee of Universitas Padjadjaran was 1015/UN6.KEP/EC/2019. The population of the study was 6,903 patients receiving surgical services at ED in 2018. After the calculation of the sample for the analytic correlative study, a minimum sample of 92 respondents was set. ${ }^{7}$

Primary data of satisfaction was obtained from the patient or relative with a consecutive sampling method. The inclusion criteria of the study were patients that received surgical services with determined decision time and willing to give their consent. The exclusion criteria of the study were unconscious patient without a relative, patients aged under 18 years old, and patients without decision time data. The respondents signed the informed consentform after the researcher explained the procedure and objectives of the study. A selfadministered ED specialized questionnaire that was translated into the Indonesian language was used. ${ }^{6}$ This questionnaire had undergone reliability and validation testing previously. The Cronbach's alpha reliability coefficient of the translated instrument was 0.957 and every item of the questionnaire was valid with Pearson product-moment correlations ranged from 0.438 to 0.935 . After the respondents filled in the ED specialized questionnaire, demographic data were obtained. Secondary data of decision time was obtained from the medical record of ED patients. This study used this specialized instrument to obtain data as specific and valid as possible. The patient's relatives' judgment regarding the ED services was considered to be able to describe the patients' judgment because of the emotional attachment of patients and their relatives in ED settings.

Patient satisfaction was categorized into satisfied and not satisfied. The category was based on the average total score of the questionnaire. The hospital service quality standards categorized decision time into $<2$ hours and $\geq 2$ hours. Decision time in less than 2 hours was considered as good service.

When the patient came to the ED, they were approached by the triage staff and categorized based on the triage indicator. After that, they were sent to the surgical ward or medical ward where they got further examinations and treatments. Decision time was the time duration since the patient had come to the surgical ward or medic ward of ED until the decision of hospitalized, surgery in the operation room, or discharge from the hospital. This study focused on ED surgical ward patients. The hospital put standard indication to be achieved at a minimum of $85 \%$ patients for decision time and patient satisfaction level. Hospitalized patients were those who were admitted to the inpatient ward or intermediate high care unit. Discharged patients were those who voluntarily go home or refused to be treated.

As weekday admissions, Monday to Friday were considered. All Saturdays and Sundays were considered weekend admissions. Admission shift was categorized into the morning, afternoon, and night with the ranged time between 7 AM to 2 PM, 2 PM to 9 PM, and $9 \mathrm{PM}$ to $7 \mathrm{AM}$, respectively.

Statistical analysis was implemented to determine the frequency distribution and association of the variables. Spearman's rank correlation test was used to determine the correlation between variables with a confidence interval of $95 \%$ was defined as statistically significant.

\section{Results}

A total of 110 subjects that met inclusion and exclusion criteria were analyzed. The data excluded were those who had filled the questionnaire before the decision time was determined $(\mathrm{n}=5)$ andsubjects withoutdecision time data $(n=2)$. Most of the respondents were the patient's relative with a proportion of 96.4\%. Table 1 summarized the demographic characteristics of the respondents. There were more female respondents $(62.7 \%)$ than male respondents. The majority of the group was in the age range of 30-64 years old. The respondents in the age range of 18-29 years old were the most satisfied (93.5\%). When classified by educational level, the majority of the respondents went to high school or lower education $(79.8 \%)$ with a satisfied category proportion at $98.9 \%$. Most of the dissatisfied respondents came from those who went to university $(33.3 \%)$.

The results of the study showed that the majority of patients visiting the ED paid with insurance $(70 \%)$. The satisfaction rate was higher for those who belong to the fee for services group (97\%). Based on the decision time, patients with insurance had a higher number in receiving decision time of fewer than 2 hours $(79.2 \%)$.

The average of respondents on weekday was 16 subjects; whilst in the weekend was 13 subjects. Most of the respondents on weekends and weekdays were satisfied with the services with a higher proportion on weekend admissions (96.3\%) than weekday admissions 
Table 1 Demographic Characteristics of Respondents

\begin{tabular}{|c|c|c|c|c|c|c|c|c|c|c|}
\hline \multirow{3}{*}{$\begin{array}{l}\text { Demographic } \\
\text { characteristic }\end{array}$} & \multirow{3}{*}{$\mathbf{n}$} & \multirow{3}{*}{$\%$} & \multicolumn{4}{|c|}{ Decision Time } & \multicolumn{4}{|c|}{ Patient Satisfaction } \\
\hline & & & \multicolumn{2}{|c|}{$<2$ hours } & \multicolumn{2}{|c|}{$\geq 2$ hours } & \multicolumn{2}{|c|}{ Satisfied } & \multicolumn{2}{|c|}{ Not Satisfied } \\
\hline & & & $\mathbf{n}$ & $\%$ & $\mathbf{n}$ & $\%$ & $\mathbf{n}$ & $\%$ & $\mathbf{n}$ & $\%$ \\
\hline \multicolumn{11}{|l|}{ Respondent } \\
\hline Patient & 4 & 3.6 & 3 & 75.0 & 1 & 25.0 & 4 & 100 & 0 & 0 \\
\hline Relative & 106 & 96.4 & 84 & 79.2 & 22 & 20.8 & 98 & 92.5 & 8 & 7.5 \\
\hline \multicolumn{11}{|l|}{ Gender } \\
\hline Male & 41 & 37.3 & 33 & 80.5 & 8 & 19.5 & 37 & 90.2 & 4 & 9.8 \\
\hline Female & 69 & 62.7 & 54 & 78.3 & 15 & 21.7 & 65 & 94.2 & 4 & 5.8 \\
\hline \multicolumn{11}{|l|}{ Age (years) } \\
\hline $18-29$ & 31 & 28.2 & 26 & 83.9 & 5 & 16.1 & 29 & 93.5 & 2 & 6.5 \\
\hline $30-64$ & 79 & 71.8 & 61 & 77.2 & 18 & 22.8 & 73 & 92.4 & 6 & 7.6 \\
\hline \multicolumn{11}{|l|}{ Educational level } \\
\hline Did not go to school & 1 & 0.9 & 1 & 100 & 0 & 0 & 1 & 100 & 0 & 0 \\
\hline High School or lower & 87 & 79.8 & 69 & 79.3 & 18 & 20.7 & 86 & 98.9 & 1 & 1.1 \\
\hline University & 21 & 19.3 & 16 & 76.2 & 5 & 23.8 & 14 & 66.7 & 7 & 33.3 \\
\hline Missing & 1 & 0.9 & & & & & & & & \\
\hline \multicolumn{11}{|l|}{ Payment } \\
\hline Insurance & 77 & 70.0 & 61 & 79.2 & 16 & 20.8 & 70 & 90.9 & 7 & 9.1 \\
\hline Fee for Services & 33 & 30.0 & 26 & 78.8 & 7 & 21.2 & 32 & 97.0 & 1 & 3.0 \\
\hline \multicolumn{11}{|l|}{ Admission Day } \\
\hline Weekday & 83 & 75.5 & 67 & 80.7 & 16 & 19.3 & 76 & 91.6 & 7 & 8.4 \\
\hline Weekend & 27 & 24.5 & 20 & 74.1 & 7 & 25.9 & 26 & 96.3 & 1 & 3.7 \\
\hline \multicolumn{11}{|l|}{ Admission Shift } \\
\hline Morning & 31 & 28.4 & 26 & 83.9 & 5 & 16.1 & 29 & 93.5 & 2 & 6.5 \\
\hline Afternoon & 63 & 57.8 & 50 & 79.4 & 13 & 20.6 & 58 & 92.1 & 5 & 7.9 \\
\hline Night & 15 & 13.8 & 10 & 66.7 & 5 & 33.3 & 14 & 93.3 & 1 & 6.7 \\
\hline Missing & 1 & 0.9 & & & & & & & & \\
\hline \multicolumn{11}{|l|}{ First Time in ER* } \\
\hline Yes & 70 & 64.2 & 54 & 77.1 & 16 & 22.9 & 66 & 94.3 & 4 & 5.7 \\
\hline No & 39 & 35.8 & 32 & 82.1 & 7 & 17.9 & 35 & 89.7 & 4 & 10.3 \\
\hline Missing & 1 & 0.9 & & & & & & & & \\
\hline \multicolumn{11}{|l|}{ Decision } \\
\hline Released & 21 & 19.6 & 17 & 81.0 & 4 & 19.0 & 20 & 95.2 & 1 & 4.8 \\
\hline Hospitalized & 55 & 51.4 & 43 & 78.2 & 12 & 21.8 & 49 & 89.1 & 6 & 10.9 \\
\hline Surgery & 31 & 29.0 & 24 & 77.4 & 7 & 22.6 & 30 & 96.8 & 1 & 3.2 \\
\hline Missing & 3 & 2.7 & & & & & & & & \\
\hline
\end{tabular}

*Emergency Room of Dr. Hasan Sadikin General Hospital

(91.6\%). The majority of the respondents came in the afternoon shift (57.8\%), and was satisfied with the services irrespective of their admission shift. Most of the patients' decision time was less than 2 hours regardless of their payment method, admission day, and admission shift.

The respondents had their first time in ED (64.2\%), and most of the patients were hospitalized after receiving surgical services in ED (51.4\%). Based on patient satisfaction, the highest rate of dissatisfied patients belonged in those who were hospitalized (10.9\%).

The data showed that $92.7 \%$ of the study subjects were satisfied with the services (Table 2 ). Based on the decision time categories, $79.1 \%$ of the patients met the service quality indicator of fewer than 2 hours. 
Table 2 Frequency Distribution of Decision Time and Patient Satisfaction

\begin{tabular}{lcc}
\hline & $\mathbf{n}$ & $\mathbf{\%}$ \\
\hline Decision Time & & \\
$<2$ hours & 87 & 79.1 \\
$\geq 2$ hours & 23 & 20.9 \\
Total & 110 & 100 \\
Patient Satisfaction & & \\
$\quad$ Satisfied & 102 & 92.7 \\
$\quad$ Not Satisfied & 8 & 7.3 \\
Total & 110 & 100 \\
\hline
\end{tabular}

Analysis of the items of the patient satisfaction questionnaire showed that most of the respondents felt satisfied with every item (Table 3). The highest satisfaction percentage referred to an item that states "the behavior of the admission staff was suitable" (96\% of the respondents are satisfied). The lowest satisfaction percentage referred to an item that states "the environment of the emergency room was calm and quiet" (68\% of the respondents are satisfied) followed by "the environment of the emergency room was hygienic" $(72 \%$ of the respondents are satisfied).

Bivariate analysis indicated that decision time and patient satisfaction had a negative correlation $(\rho=-0.144)$. Spearman's rho showed a weak correlation between the variables. The

Table 3 Patient Satisfaction Level regarding 20 Items of Questionnaire

\begin{tabular}{ll}
\multicolumn{1}{c}{ Statements } & $\mathbf{S}^{*}$ \\
\hline Nurses care about my treatment & $94 \%$ \\
Nurses inform me about the remaining the treatment & $95 \%$ \\
Nurses attended to me patiently & $92 \%$ \\
Nurses relieved me of the pain well & $90 \%$ \\
Admission staff guided me appropriately & $93 \%$ \\
The behavior of the admission staff was suitable & $96 \%$ \\
The environment of the emergency room was calm and quiet & $68 \%$ \\
The emergency room was well equipped & $88 \%$ \\
The environment of the emergency room was hygienic & $72 \%$ \\
The physician told me about my treatment course & $92 \%$ \\
The behavior of the physician was respectful & $94 \%$ \\
The physician's explanation about the remaining treatment was enough & $93 \%$ \\
The physician spent a sufficient time examining me & $89 \%$ \\
The waiting time before seeing the doctor was appropriate & $82 \%$ \\
The waiting time before the admission process was appropriate & $86 \%$ \\
I would recommend this hospital to my acquaintances & $89 \%$ \\
I am satisfied with the quality of services in the emergency room & $84 \%$ \\
The emergency room of this hospital is well functioning & $93 \%$ \\
The family of the patient is respected in this hospital & $89 \%$ \\
The family can spend an appropriate amount of time beside the patient & $94 \%$ \\
\hline
\end{tabular}

Note: ${ }^{*} \mathrm{~S}=$ Percentage of satisfied respondents with an average total score range between 2.51-4.00 
Table 4 Bivariate Analysis on Decision Time and Patient Satisfaction

\begin{tabular}{llccccccc}
\hline \multirow{2}{*}{ Variable } & \multirow{2}{*}{ Category } & \multicolumn{2}{c}{ Satisfied } & \multicolumn{2}{c}{ Not Satisfied } & \multicolumn{2}{c}{$\boldsymbol{\rho}$} & p-value* $^{*}$ \\
\cline { 3 - 6 } & & $\mathbf{n}$ & $\mathbf{0}$ & $\mathbf{n}$ & $\mathbf{0}$ & & \\
\hline \multirow{2}{*}{ Decision Time } & $<2$ hours & 79 & 77.5 & 8 & 100 & -0.144 & 0.067 \\
& $\geq 2$ hours & 23 & 22.5 & 0 & 0 & & \\
\hline
\end{tabular}

Notes: *Not statistically significant with CI of 95\%.

correlation between patient satisfaction and decision time was not statistically significant with $\mathrm{p}$-value $=0.067(\mathrm{CI}=95 \%)$ (Table 4$)$.

\section{Discussion}

This study has shown that most of the subjects are satisfied with the health services provided in the emergency department of Dr. Hasan Sadikin General Hospital. The finding is similar to a study in the USA among trauma patients, ${ }^{8}$ as well as a study in Palestine that shows a high overall satisfaction of ED patients. ${ }^{9}$ The measurement of healthcare service quality felt by the patient is defined as patient satisfaction. ${ }^{6}$ Other than the achieved standard of satisfaction indicator, most of the subjects have a decision time of fewer than 2 hours. However, our result has shown an insignificant correlation between decision time and patient satisfaction. This intriguing finding is contrary to previous studies, suggesting a significant relationship between patient satisfaction and time-related service quality indicators.6,9-13

Most of the respondents in our study are the relatives of the patients, as conducted in other studies. ${ }^{11,6}$ The majority of our respondents are female similar to another study in Medan, Indonesia. ${ }^{12}$ However, in some other places such as in Iran the majority of relatives in the study are male, aged older than 30 years old. ${ }^{11,14}$ Similar to study in Lampung, Indonesia, the majority of subjects is ranged within 18-29 years old and they are more satisfied with the services rather than respondents from the age group of 30-64 years old, ${ }^{13}$ however, a study in the USA ${ }^{8}$ shows otherwise, that younger respondents gave low patient satisfaction scores. Similar to another study on ED in Indonesia and Iran, the majority of the respondents have an education level of high school or lower education. ${ }^{11,13}$ The frequency of dissatisfied respondents is highest on those who have to university background, similar to the result in another study in Iran. ${ }^{11}$

Most of the respondents paid for the services with insurance. The satisfaction rate is higher in the fee for the services group. The respondents with insurance were satisfied with the service and there is a significant relationship between hospital service quality and insurance patient satisfaction. ${ }^{15}$ Most of the respondents in our study have come on a weekday and in the afternoon shift. Interestingly, in other studies most of the respondents have come on vacation days and night shift. ${ }^{14}$ In the present study, most of the patients are further hospitalized, whereas in studies in Iran most of the ED patients are discharged. ${ }^{11,14}$

The emergency department is one of the hospital services that provide first treatment for the patient who comes on his own to the hospital or the continuation of services for referred patient or patients came with the Public Safety Center. It has a role to give accurate, fast, and careful emergency services. The services must be available for wide-range of socioeconomic levels and corresponding to people's needs. ${ }^{16}$ Due to its unique dynamic of works, ED has an important role in affecting patient satisfaction. This also indicated that a specialized instrument to measure ED patient satisfaction level is needed. ${ }^{6}$

The percentage of distribution of the answers to questionnaire items shows that the highest satisfaction percentage refers to items that describe the ED staff, which is considered high.,11 Interestingly, this study shows that the lowest satisfaction percentage refers to items described in the environment of ED, in opposite to the study in Palestine that ED environment has been considered to have a high rank of satisfaction..$^{9}$ The study in Iran hospital ED shows that items referring to ED environment cleanness and neatness have a low satisfaction level, similar to our study. ${ }^{11}$ The physical aspects of ED are on the average level of satisfaction with the highest level on the cleanliness of ED. ${ }^{14}$

Patient satisfaction can be reviewed based on various aspects. Based on hospital management, decision time is a quality indicator that has implications for the patient. However, satisfaction is multidimensional. ${ }^{17}$ Thus, patient satisfaction is not only defined 
by decision time. This study discovers decision time is not the main factor affecting patient satisfaction and had a weak correlation which was not statistically significant. This also indicated that further research is needed to determine factors affecting surgical patient satisfaction. There is a strong correlation between physician interpersonal skills and patient satisfaction.18 Various studies have found a significant relationship between patient satisfaction and response time, service procedure, also ED environmental coziness. ${ }^{12,13}$ Repeated information from staff regarding the delayed medical examination received by the patients has a positive effect on satisfaction level in comparison with not receiving any information.

This study has measured patient satisfaction based on their perception of every aspect of emergency department satisfaction on the questionnaire. Another study in ED with the SERVQUAL approach has shown that there is a significant relationship between patient satisfaction with dimensions of reliability, responsiveness, tangibility, assurance, and empathy. The tangibility is the dominant variable in determining patient satisfaction.19

The limitation of the study is among others the number of human resources and data collection time. Due to the unique dynamic of the ED and patient or relative emotional situation, there is a quite long time gap between visit time and the ethically appropriate condition for the researcher to approach the patients.

In conclusion, there is no correlation between patient satisfaction and decision time. Additionally, decision time is not the main factor in determining patient satisfaction. Most of the respondents are satisfied with the services. Further studies to discover factors affecting patient satisfaction in the emergency department are needed. Moreover, the health care provider should maintain and improve health services quality, focusing on satisfaction items.

\section{References}

1. Al-Abri R, Al-Balushi A. Patient satisfaction survey as a tool towards quality improvement. Oman Med J. 2014;29(1):3-7.

2. Finch T, Shim TN, Roberts L, Johnson 0 . Treatment satisfaction among patients with moderate-to-severe psoriasis. J Clin Aesthet Dermatol. 2015;8(4):26-30.

3. Fatima T, Malik SA, Shabbir A. Hospital healthcare service quality, patient satisfaction and loyalty: An investigation in context of private healthcare systems. InternationalJournal ofQuality \& Reliability Management. 2018;35(6):1195-214.

4. Havens J, Peetz A, Do W, Cooper Z, Kelly E, Askari R, et al. The excess morbidity and mortality of emergency general surgery. J Trauma Acute Care Surg. 2015;78(2):30611.

5. McCord C, Ozgediz D, Beard JH, Debas HT. General surgical emergencies. In: Debas HT, Donkor P, Gawande A, Jamison DT, Kruk ME, Mock CN, editors. Essential surgery: diseases control priorities. 3rd ed (Volume 1). Washington, DC: World Bank Publication; 2015. Chapter 4. p. 61-76.

6. Atari M, Atari M. Brief Emergency Department Patient Satisfaction Scale (BEPSS); development of a new practical instrument. Emerg (Tehran). 2015;3(3):103-8.

7. Dahlan MS. Besar sampel dalam penelitian kedokteran dan kesehatan. Jakarta: Epidemiologi Indonesia;2016.

8. Rogers F, Horst M, To T, Rogers A, Edavettal $\mathrm{M}, \mathrm{Wu} \mathrm{D}$, et al. Factors associated with patient satisfaction scores for physician care in trauma patients. J Trauma Acute Care Surg. 2013;75(1):110-4.

9. Amro N, Kamel AMA, Qtait M, Yagi H, Amro B, Amro R, et al. Factors affect patients satisfaction in emergency departments in Palestine. Journal of Health, Medicine and Nursing. 2018;54:50-6.

10. Messina G, Vencia F, Mecheroni S, Dionisi $S$, Baragatti L, Nante N. Factors affecting patient satisfaction with emergency department care: an Italian rural hospital. Glob J Health Sci. 2014;7(4):30-9.

11. Soleimanpour H, Gholipouri C, Salarilak S, Raoufi P, Vahidi RG, Rouhi AJ, et al. Emergency department patient satisfaction survey in Imam Reza Hospital, Tabriz, Iran. Int J Emerg Med. 2011;4:2.

12. Sinurat S, Perangin-angin $I H$, Sepuh JCL. Hubungan response time perawat dengan tingkat kepuasan pasien BPJS di Instalasi Gawat Darurat. Jurnal Penelitian Keperawatan. 2019;5(1):1-9.

13. Nurlina D, Rifai A, Jamaluddin J. Faktorfaktor yang memengaruhi kepuasan pasien instalasi gawat darurat Rumah Sakit TNI AD Tk Iv 02.07. 04 Bandar Lampung tahun 2017. Jurnal Ilmu Kesehatan Masyarakat. 2019;8(03):78-88.

14. Eshghi M, Rahmani F, Derakhti B, Abdollahi $\mathrm{F}$, Tajoddini S. Patient satisfaction in the 
emergency department: a case of Sina hospital in Tabriz. Journal of Emergency Practice and Trauma. 2016;2(1):15-20.

15. Yuniarti S. Hubungan antara kualitas pelayanan rumah sakit dengan tingkat kepuasan pasien BPJS di ruang perawatan RSUD Sultan Syarif Mohamad Alkadrie Kota Pontianak tahun 2015. Jurnal ProNers. 2015;3(1):11039.

16. Menteri Kesehatan Republik Indonesia. Peraturan Menteri Kesehatan Republik Indonesia Nomor 47 tentang Pelayanan Kegawatdaruratan. Jakarta: Kementerian Kesehatan Republik Indonesia; 2018.
17. Goddard GJ, Raab G, Ajami RA, Gargeya VB. Customer relationship management: a global perspective. Hampshire, England: Gower Publishing Limited;2012.

18. Soremekun OA, Takayesu JK, Bohan SJ. Framework for analyzing wait times and other factors that impact patient satisfaction in the emergency department. J Emerg Med. 2011;41(6):686-92.

19. Septiani A. Pengaruh faktor-faktor kualitas pelayanan terhadap kepuasan pasien di instalasi gawat darurat RSUD Kabupaten Sumedang. Coopetition. 2016;7(1):1-22. 